\title{
An Outbreak of Herbaspirillum Genus Bacteria Bloodstream Infections in Immunocompetent Pediatric Patients
}

\author{
Immünkompetan Çocuklarda Herbaspirillum Cinsi Bakterilere Bağlı \\ Kan Akımı Enfeksiyonu Salgını
}

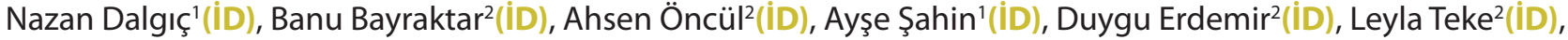

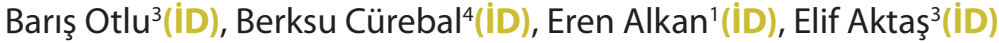 \\ ${ }^{1}$ Clinic of Pediatrics, Şişli Hamidiye Etfal Training and Research Hospital, Istanbul, Turkey \\ ${ }^{2}$ Clinic of Clinical Microbiology, Şişli Hamidiye Etfal Training and Research Hospital, İstanbul, Turkey \\ ${ }^{3}$ Clinic of Medical Microbiology, Şişli Hamidiye Etfal Training and Research Hospital, İstanbul, Turkey \\ ${ }^{4}$ Medical Microbiology Laboratory, Şişli Hamidiye Etfal Training and Research Hospital, İstanbul, Turkey
}

Cite this article as: Dalgı̧ N, Bayraktar B, Öncül A, Şahin A, Erdemir D, Teke L, et al. An outbreak of Herbaspirillum genus bacteria bloodstream infections in immunocompetent pediatric patients. J Pediatr Inf 2021;15(3):e146-e151.

\section{Abstract}

Objective: The study aimed to report the investigation of an outbreak that occurred by Herbaspirillum huttiense in the blood culture of 12 patients in a clinic for 1.5 months.

Material and Methods: The clonal relationship was investigated by "arbitrarily primed" polymerized chain reaction (AP-PCR) and "pulsed-field" gel electrophoresis (PFGE).

Results: The isolates were identified as Herbaspirillum huttiense/aquaticum (score value $>2$ ) with Bruker MS and Burkholderia cepacia or Cupriavidus pauculus with the Phoenix automated system. With the $16 \mathrm{~S}$ rDNA sequence analysis, the isolate was identified as 99\% Herbaspirillum huttiense. A common feature for the patients was identified as their reporting to the pediatric emergency clinic; environmental screening was directed to this clinic. Herbaspirillum huttiense growth was detected in a $250 \mathrm{~mL}$ saline bag which was in use, nine injectors were prepared for use by filling with saline solution and in ready-to-use patches. With APPCR and PFGE, all patients and environmental isolates examined with $A P-P C R$, six representative patients and three environmental isolates examined with PFGE were found to be indistinguishable.

Conclusion: The outbreak resulting from Herbaspirillum huttiense is reported for the second time in the literature, and the first to report the source of the outbreak.

Keywords: Herbaspirillum, outbreak, sepsis, immunocompetent, children
Öz

Giriş: Bu çalışma, 1.5 aylık sürede kliniğimizde 12 hastanın kan kültürlerinde üreyen Herbaspirillum huttiense kaynaklı bir salgının araştırma bulgularını bildirmektedir.

Gereç ve Yöntemler: Klonal ilişki, "rastgele hazırlanmış" polimeraz zincir reaksiyonu (AP-PCR) ve "darbeli alan" jel elektroforezi (PFGE) ile incelenmiştir.

Bulgular: İolatlar, Bruker MS ile Herbaspirillum huttiense/aquaticum (skor değeri >2) ve Phoenix otomatik sistemi ile Burkholderia cepacia veya Cupriavidus pauculus olarak tanımlandı. 16S rDNA sekans analizi ile izolat, \%99 Herbaspirillum huttiense olarak raporlandı. Hastaların ortak bir özelliği, pediatri acil kliniğine başvurmaları olarak belirlendi; dolayısıyla çevre taraması bu kliniğe yönlendirildi. Herbaspirillum huttiense üremesi, kullanımda olan 250 mL'lik salin solüsyonu ile doldurularak kullanıma hazırlanan dokuz enjektörde ve kullanıma hazır bantlarda tespit edildi. AP-PCR ve PFGE ile yapılan inceleme AP-PCR ile incelenen tüm hastalar ve çevresel izolatlarda, PFGE ile incelenen üç çevresel izolatın ve altı temsili hastada birbirlerinden ayırt edilemez olduğu tespit edildi.

Sonuç: Çalışmamız, Herbaspirillum huttiense kaynaklı salgının bildirildiği literatürdeki ikinci ve salgının kaynağını bildiren ilk çalışmadır.

Anahtar Kelimeler: Herbaspirillum, salgın, sepsis, immünkompetan, çocuk

Correspondence Address/Yazışma Adresi

Nazan Dalgıç

Şişli Hamidiye Etfal Eğitim ve Araştırma Hastanesi,

Çocuk Enfeksiyon Hastalıkları Kliniği,

istanbul-Türkiye

E-mail: nazandalgic@ttmail.com 


\section{Introduction}

Health-care-associated infections are considered the most common adverse event that threatens the safety of patients worldwide (1). Similar to endemic hospital-acquired infections, infectious outbreaks greatly contribute to morbidity and mortality. Investigation of outbreaks has led to the discovery of different types of pathogen reservoirs. For example, medical drugs and other fluids used for patient care represent well-known sources of hospital-acquired outbreaks (2).

Herbaspirillum genus bacteria can be gram-negative, curved or rod shaped, nitrogen-binding, urease, catalase and oxidase-positive aerobic bacteria (3). They are usually found in the rhizosphere layer. They are found in the soil, cereal roots, groundwater and drinking water distribution systems (4). Herbaspirillum bacteria are rarely associated with human infections. The isolation of Herbaspirillum from human infection sites was reported for the first time in the 1980s (5). Herbaspirillum spp. has been detected in the blood of patients with cystic fibrosis (6), leukemia (2,7), cellulitis and bacteremia (8), and from sputum (6). They have been also been detected in arterial walls of aortic aneurysms (9). Even if rare, Herbaspirillum species can also be a factor in hospital-acquired and community-acquired hospital infections (10). It is phylogenetically and phenotypically very similar to Burkholderia cepacia complex and is therefore often misidentified (2).

This study reports the investigation of an outbreak due to the growth of Herbaspirillum genus bacteria in the blood cultures of 12 patients monitored at the department of pediatrics, Sisli Hamidiye Etfal Training and Research Hospital, University of Health Sciences for 1.5 months, starting from 21.07.2016. Our study reports the second outbreak in literature due to Herbaspirillum genus bacteria, and the first to detect the source.

\section{Materials and Methods}

Between July and September 2016, 12 pediatric patients were included in the study, some were diagnosed as non-infectious but later developed clinical sepsis after hospitalization. The patients were monitored by different teams at different pediatric clinics and were shown to have Herbaspirillum genus bacterial growth in the blood cultures sent to the Medical Microbiology Laboratory.

The study was approved by the institutional ethics committee $(\neq 825 / 17)$. Written informed consent was obtained for each patient from their parent or guardian.

\section{Environmental Sampling}

In order to investigate the possible source of the outbreak, environmental samples were taken from the Pediatric Emergency Clinic and from the clinics where the patients were treated. The first environmental samples, 2 unopened and 1 opened $100 \mathrm{~mL} 0.9 \%$ saline solutions were taken as an external edge swab and internal fluid from the pediatric emergency blood collection room 45 days from the outbreak. The following samples were taken for plating: $70 \%$ alcohol liquid, intravenous cannula surfaces, the liquid of 4 ready to use syringes filled with saline solution, plasters ready to be used on patients, and liquid from a $250 \mathrm{~mL}$ polyphexylated polypharmacy opened five days prior and kept in wait. Again, samples were taken from the blood collection box at the pediatric emergency red zone intervention room, treatment tray, ready plasters, door handle, oxygen chamber, the outer cover and direct fluid of batticon, desk and keyboard of the service counter, observation room faucet, shared stethoscope and oxygen cylinder in the steam room. In terms of possible sources, samples were taken from alcohol, batticon and saline solutions and the environment where patients were monitored. After two days, samples were taken again from 60 emergency syringes filled with saline solution and ready for use at the pediatric emergency blood collection and intervention room. A day later, 6 pieces of unopened and ready to use 250 $\mathrm{mL}$ proflex saline solution and 3 unopened $250 \mathrm{~mL}$ proflex saline solution packages taken directly from the pharmacy store were sampled at the pediatric emergency polyclinic. Sampling was performed by taking the liquids, outer surface swab and entrance swab. The samples taken were plated on sheep blood agar and McConkey. The samples were evaluated at 24 and 48 hours. Also, the sampled proflex saline solution liquid sample was plated into the BACTEC-FX (Becton Dickinson) blood culture bottle. A total of 110 samples were examined within the scope of environmental screening.

\section{Bacterial Cultures and Identification}

Blood culture isolates from 12 patients, obtained from 21 July to 8 September 2016 and 11 environmental isolates were included in this study. Gram stain showed gram-negative bacilli.

Commercially available three automated systems, namely Phoenix 100 ID/AST (Becton Dickinson, Diagnostics, Sparks, MD, USA), VITEK 2 Compact (BioMeriuex, St.Louise, MO, USA) and MicroScan (Beckman Coulter, Brea, CA, USA), and two different matrix-assisted laser desorption ionization-time of flight mass spectrometry (MALDI-TOF MS), namely Bruker MS (Bruker Daltonics, Bremen Germany) and VITEK MS (Database Version 2.0) (BioMeriuex, St.Louise, MO, USA) were used for identification of microorganisms.

For $16 \mathrm{~S}$ rDNA sequencing, extracted DNA (QiaSymphony total DNA extraction kit) was amplified using the primers p8FPL 5'-AGT TTG ATC ATG GCT CAG-3' and p806R 5'-GGA CTA CCA GGG TAT CTA AT-3' and GeneAmp PCR System 9700 (Applied Biosystems, USA). Sequences were obtained using ABI Prism 310 Genetic Analyzer (Applied Biosystems, USA) and compared with known bacterial sequences available at NCBI gene bank. For species-level identification, the data with E-value 0.0, and the percentage of similarity $>99 \%$ was used. 
Minimal inhibitor concentrations of ceftriaxone, ceftazidime, cefotaxime, meropenem, imipenem, ciprofloxacin, levofloxacin and amikacin were determined by using the gradient test method (ETEST, BioMeriuex, France). Results were interpreted according to CLSI guidelines (11).

\section{Clonal Relationship}

Clonal relationships of the strains were investigated by Arbitrarily Primed Polymerase Chain Reaction (AP-PCR) and Pulsed Field Gel Electrophoresis (PFGE) methods. AP-PCR amplifications were performed with M13 primer (5'-GAG GGT GGC GGT TCT-3') according to the following protocol: $94^{\circ} \mathrm{C}$ for $5 \mathrm{~min} ; 40 \mathrm{cycles}$ of $94^{\circ} \mathrm{C}$ for $1 \mathrm{~min}, 40^{\circ} \mathrm{C}$ for $1 \mathrm{~min}$, and $72^{\circ} \mathrm{C}$ for $2 \mathrm{~min} ; 72^{\circ} \mathrm{C} 10 \mathrm{~min}$.

PFGE typing was carried out using the modified protocol of Durmaz et al. (12). Briefly, Spe-1 enzyme restricted chromosomal DNAs were analyzed by electrophoresis on CHEF-DR II system (Bio-Rad, Nazareth, Belgium) with the initial switch time of 2s, the final switch time 50s over 22 hours (13). Photographs of banding profiles saved as a TIFF file were subjected to cluster analysis using the GelCompar version 6.6 software package (AppliedMaths, Kourtrai, Belgium) using the unweighted pair group method with arithmetic mean (UPGMA) and the Dice coefficient. Isolates having $\geq 95 \%$ similarities were accepted as the same PFGE type or clone.

\section{Chart Review and Preventive Actions}

When the microbiology department stated that there were 12 Herbaspirillum spp. within 1.5 months, clinicians were warned and an infection control committee was formed. During the meeting, patient charts were assessed for common medications and exposures, and the pediatric emergency service, which is the first reporting point of the hospital drew attention as the common factor for all cases. For this reason, it was decided to perform the first screening in all areas where invasive procedures were performed in the pediatric emergency department.

\section{Results}

\section{Setting and the Patients}

The growth of Herbaspirillum was observed in the blood cultures of 12 patients who were hospitalized and treated at the hospital after reporting to the pediatric emergency department for various reasons within 1.5 months. All patients were admitted to the hospital from the pediatric emergency clinic, where vascular access opened and the patients were hospitalized. Three patients were followed up in the pediatric intensive care unit and the other patients were followed up in different pediatric clinics. Four patients were hospitalized for acute gastroenteritis, three for sepsis, two for febrile neutropenia, one for urinary tract infection, one for pertussis and one for drowning. The mean age was $24.81 \pm 31.13$ months (range 3-108 months). Five patients were male and 8 were female. Table 1 shows the demographic characteristics and clinical information of the patients. Infection in the bloodstream occurred after a mean of three days of hospitalization (range 2-6 days). Eight patients were started on ceftriaxone. On the 3 rd day of ceftriaxone treatment, one of the two patients who developed resistant fever was switched to piperacillin-tazobactam treatment while the other was switched to meropenem treatment. One of the four remaining patients was started on ampicillin-amikacin, another on piperacillin-tazobactam and the other two on meropenem. Treatment of the patient started on piperacillin-tazobactam was switched imipenem upon developing resistant fever. All patients were discharged without any complications. The mean length of hospital stay was $10.18 \pm 2.04$ days (7-14).

Table 1. Patient demographics and clinical information

\begin{tabular}{|l|c|c|c|c|c|c|c|}
\hline Patient & Age (months) & Sex & Clinical diagnosis & Following Clinic & Day of BSI & Treatment received & Outcome \\
\hline 1 & 34 & Male & Sepsis & Pediatric infection & 3 & Ceftriaxone/meropenem & Discharged day 10 \\
\hline 2 & 10 & Female & Sepsis & Pediatric infection & 6 & Pip-taz/Imipenem & Discharged day 12 \\
\hline 3 & 6 & Female & Gastroenteritis & Pediatric infection & 2 & Ceftriaxone & Discharged day 8 \\
\hline 4 & 21 & Female & Febrile neutropenia & Pediatric hematology & 4 & Meropenem & Discharged day 14 \\
\hline 5 & 5 & Male & Pertusis & Pediatric infection & 4 & Ceftriaxone & Discharged day 10 \\
\hline 6 & 25 & Male & Gastroenteritis & Pediatric infection & 3 & Ceftriaxone/pip-taz & Discharged day 11 \\
\hline 7 & 108 & Male & Gastroenteritis & Pediatric infection & 2 & Ceftriaxone & Discharged day 8 \\
\hline 8 & 48 & Female & Drowning in the water & Pediatric intensive care & 2 & Ceftriaxone & Discharged day 10 \\
\hline 9 & 10 & Female & Febrile neutropenia & Pediatric hematology & 5 & Meropenem & Discharged day 7 \\
\hline 10 & 3 & Female & Gastroenteritis & Pediatric infection & 3 & Ampisillin-amikacin & Discharged day 12 \\
\hline 11 & 3 & Male & Sepsis & Pediatric infection & 3 & Ceftriaxone & Discharged day 10 \\
\hline 12 & 2 & Female & Urinary tract infection & General pediatrics & 3 & Ceftriaxone & Discharged day 7 \\
\hline BSI: Bloodstream infection, Pip-taz: piperacillin-tazobactam. & & & \\
\hline
\end{tabular}




\section{Environmental Sampling}

Result of the environmental screening performed at the Pediatric Emergency Clinic on 05.09.2016; Herbaspirillum growth was present in samples taken from the blood collection room, four prepared syringes used in the withdrawal of saline solution, one piece of plaster cut ready for use and in the $250 \mathrm{cc}$ Proflex saline solution, which was opened five days prior and still in use. No growth was observed in the samples taken from the intervention rooms. In the second screening conducted at the pediatric emergency clinic two days later based on the detected growth; Herbaspirillum growth was observed to have occurred in samples taken from ready to use syringes filled with saline solution in the blood collection chamber and intervention rooms; one out of 30 syringes in the treatment rooms and four out of 40 syringes (total of 5 pieces) in the blood collection room. In order to determine whether or not there was commercial contamination, $250 \mathrm{~mL}$ Proflex saline solutions were inoculated after a day and this included six ready to use unopened packets at the pediatric emergency clinic and three unopened packets from the pharmacy. No growth was observed in the samples tested. It was therefore understood that the problem was not commercial contamination.

\section{Bacterial Cultures and Identification}

Gram stain showed Gram-negative rods. Isolates were identified as Herbaspirillum huttiense/Herbaspirillum aquaticum using matrix-assisted laser desorption ionization-time of flight mass spectrometry (MALDI-TOF MS; Bruker Daltonics, Germany) with an assessment score 2. A Phoenix 100ID/ASD automated microbiology system (Becton Dickinson Diagnostics, Sparks, $\mathrm{MD}$ ) identified the isolate as Burkholderia cepacia complex/Cupriavidus pauculus. The isolate was tested with two other automated commercial microbiology systems, Vitek 2 (Bio-Mérieux, St Louise, MO), and MicroScan (Beckman-Coulter Inc, Brea, CA), as well as with a second MALDI-TOF, VITEK MS (Bio-Mérieux, St Louise, MO). Vitek 2 (v.2.0) identified the isolate as Burkholderia cepacia complex. Neither the MicroScan nor Vitek MS (database v2.0) was able to identify the isolate.

For $16 \mathrm{~S}$ rDNA sequencing, 650 nucleotides were analyzed and the strain was identified as $99 \%$ Herbaspirillum huttiense (GenBank accession no. KU305714.1). All isolates were susceptible to ceftriaxone $(0.125-0.5 \mathrm{mg} / \mathrm{L})$, ceftazidime $(0.125-0.5$ $\mathrm{mg} / \mathrm{L})$, cefotaxime (0.125-0.38 mg/L), meropenem (0.003)-0.012 $\mathrm{mg} / \mathrm{L})$, imipenem $(0.032-0.19 \mathrm{mg} / \mathrm{L})$, ciprofloxacine $(0.5-0.75$ $\mathrm{mg} / \mathrm{L})$, levofloxacin $(0.25 \mathrm{mg} / \mathrm{L})$ and amikacin $(4 \mathrm{mg} / \mathrm{L})$.

\section{Clonal Relationship}

AP-PCR and PFGE results were in agreement with each other. AP-PCR of all patients and environmental isolates had precisely the same banding pattern. PFGE of representative isolates, belonging to six patients and three environmental sources, established that all the strains were the same/indistinguishable (Figure 1).

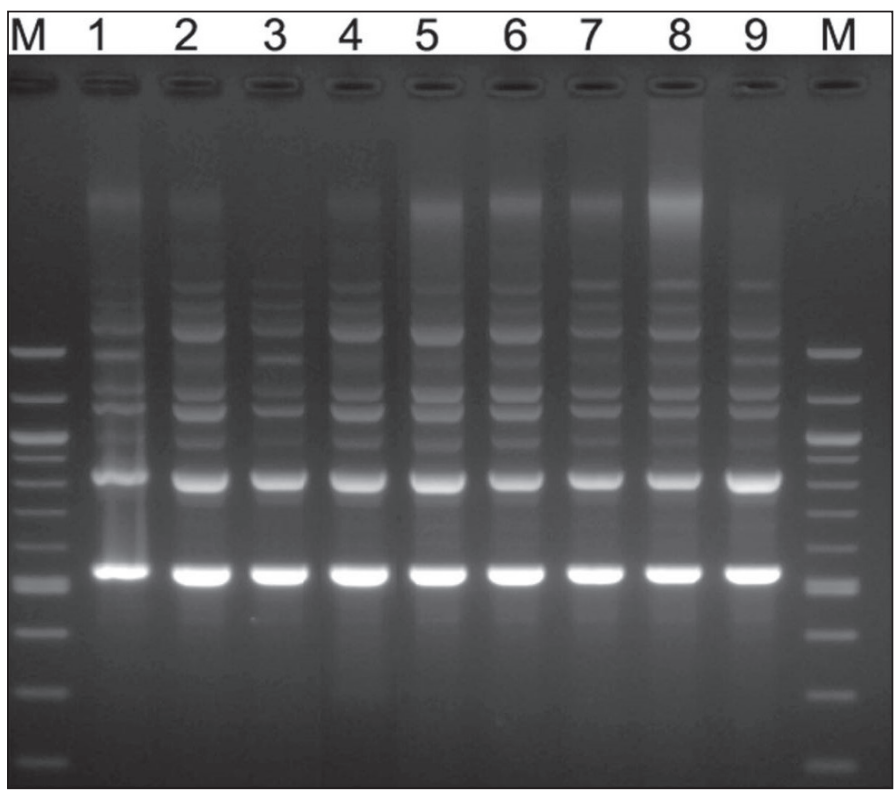

Figure 1. PFGE banding pattern of outbreak Herbaspirillum isolates. M: DNA marker.

\section{Chart Review and Preventive Actions}

In the investigations, it was observed that the shelves where the materials were placed in the child emergency unit could not be easily cleaned and the edges were damaged due to the material made of wood. Also, materials were stored in excess, the saline solution was withdrawn into the syringes in advance and to be ready for use on the patient and the vascular access was washed with these syringes.

It was suggested by the Infection Control Committee that, liquids such as saline solution used for the preparation of disposable drugs for patients and washing catheter should not be withdrawn and kept. It was also recommended that the entry point of syringes must be disinfected with alcohol for $15 \mathrm{~s}$ before usage and multidose drug-serum should be avoided as much as possible. Additionally, it was suggested that antiseptics applied to the skin during blood collection and invasive procedures be allowed to stand for an appropriate period time ( $2 \%$ chlorhexidine gluconate until dryness, $10 \%$ povidone iodine allowed to stand for two minutes before starting the process), replacement of material containers and table, smooth and easy to clean. Since the same growth was in the media cultures taken, it was recommended that media surfaces and places are disinfected for at least 10 minutes with $1 / 10$ bleach (chlorine tablet solution corresponding to $5000 \mathrm{ppm}$ ), cleaning of units at least twice daily, cleaning without waiting period if necessary, and use of medium level disinfectant in addition to water and detergent in daily cleaning. It was also recommended to use 1/100 bleach (chlorine tablet solution corresponding to $500 \mathrm{ppm}$ ) or rapid surface disinfectant sprays (containing alcohol and quantum ammonium compounds) in the disinfection process after mechanical cleaning of all surfaces. Retraining of personnel was 
Dalgıç et al.

suggested to ensure that liquid soap and paper towel in washrooms are checked twice a day and replaced when they run out. Daily control of hand antiseptics should be made and writing of dates upon opening new ones, and to ensure that material (test tubes, syringes, serum, etc.) stock supply is done daily at a minimum level.

\section{Discussion}

Herbaspirillum species was described three decades ago as a Gram-negative, rod-shaped member of the Betaproteobacteria class of bacteria, including Burkholderia, Ralstonia, and other plant-associated bacteria. Information on Herbaspirillum in clinical microbiology is still limited $(2,6,8,14,15)$ and data on possible pathogenicity-associated characteristics are inadequate (16). A couple of Herbaspirillum species have been identified and studied; however, those reported to be human pathogens only make up a small fraction (3). One of the earliest human infections documented for this organism was made in 2005 from the wound isolate of a 49-year-old homeless man with a chronic liver disease history (8). The emergence of new and effective technology has led to the reclassification of Herbaspirillum and other unclassified human isolates obtained as early in 1978 from infections of the ear, eye, knee, urine, oropharynx, gastrointestinal tract, blood, and respiratory tract (5). The growth of Herbaspirllium was reported for the first time by Ziga et al. in a 2-year-old acute lymphoblastic leukemia (ALL) diagnosed female patient. The growth was demonstrated by 16 s rRNA gene analysis and this was treated with $20 \mathrm{mg} / \mathrm{kg}$ meropenem every 8 hours for a total of 7 days (2). Regunath et al. reported the growth of Herbaspirillum in a 46-year-old male patient with community acquired pneumonia. Identification was achieved using a MALDI-TOF system and the patient was treated with doxycycline, piperacillin-tazobactam for 14 days (3). Chen et al. reported a case of Herbaspirillum growth in a 48-year-old ALL diagnosed female patient. 16s rRNA gene sequencing method was used to establish growth of the agent. The agent was also established to be multi-drug resistant (7). Suwantarat et al. reported Herbaspirillum growth in a 65-year-old patient with end-stage renal failure and multiple myeloma. The agent was determined with gas-liquid chromatography. The patient was lost on the fourth day of admission even though the agent was sensitive to antibiotic drugs (4). Spilker et al. carried out a study between 2000 and 2007 on 28 patients with ages ranging from 20 months to 59 years, having varying cystic fibrosis. Herbaspirillum growth was observed in the sputum culture of 27 patients and the blood culture of one patient (6).

Chemaly et al. reported the first hospital-based cluster of Herbaspirillum spp. infections in cancer patients as well as ensuing sporadic cases of hospital-and community-onset infections (10). They identified eight cases of Herbaspirillum species. Their isolates from the first 5 clustered cases were initially misidentified as B. cepacia, and available isolates from 4 of their cases were indistinguishable. Three of their following cases were identified by prospective surveillance and had different PFGE patterns. They didn't identify any environmental source or common mechanism of acquisition. Our study is the second study after Chemly et al.'s study to report an outbreak caused by Herbaspirillum type bacteria, but the first study that determined its source. When the first strain was detected in the hospital, the hospital department where the patient had been treated was contacted and it was learnt that the growth was considered to be significant due to symptoms of bacteremia, and antibiotic treatment was started. During the follow-ups, the possibility of an outbreak was considered due to new growths of the same bacteria and an infection control committee was urgently formed. The patients were followed by different teams in different pediatric clinics; some of them were hospitalized with non-infectious diagnoses but after the hospitalization, clinical sepsis developed and all of them had a response to antibiotic treatment. It was made known that patients entered the hospital through the emergency pediatric clinic and their vascular access was opened. The result of environmental screening at the emergency pediatric clinic showed the growth of Herbaspirillum species in a $250 \mathrm{~mL}$ saline solution bag that was in use, in nine syringes filled with saline solution, and in ready-to-use plasters. All patients and environmental isolates with AP-PCR, representative six patients and three environmental isolates were determined to be the same/indistinguishable. Once the source was identified, the outbreak was controlled by infection control measures and training. No new cases were observed during the 2-year follow-up period. In order to work fast under emergency conditions, the withdrawal and keeping of saline solution in syringes, opening and keeping saline solutions in wait and the use of plasters by emergency personnel are considered to be wrong. Therefore, a new set of materials should be used for every patient in each procedure. In this study, it was realized that some of the methods applied to save time are improper practices and these result in bigger problems. Personnel training and disinfection of working environments are important in preventing such outbreaks. Collaboration between clinicians, microbiologists and the infection control committee and nurses also helped to control and prevent further outbreaks. Herbaspirillum species has been often misidentified due to its close phylogenetic and phenotypic resemblance to Burkholderia cepacia complex $(5,9,17)$. The commonly used automated systems for bacterial identification, such as the BD Phoenix$\mathrm{TM}$, MicroScan, and the Vitek2 ${ }^{\circledR}$, have misidentified isolates of Herbaspirillum spp. As B. cepacia complex, C. pauculus, and Ochrobactrum anthropi $(2,6,8,10,16)$. Thus, uncommon non-lactose-fermenting gram-negative bacteria identified by automated systems should be referred to other methods of identification. Although MALDI-ToF MS analysis is becoming routinely used for organism identification, there is limited data with regards to the identification of Herbaspirillum spp. (4). Between 2000 and 2007, the Burkhholderia cepacia Research Laboratory 
and Repository at the University of Michigan, Ann Arbor, isolated Herbaspirillum from 28 sputum cultures and one blood isolate referred from 23 cystic fibrosis treatment centers in the United States. Out of these isolates, 19 (68\%) were initially identified as Burkholderia (16). Between 2006 and 2011, Chemaly et al. reexamined nine blood, 24 sputum and 13 other sources culture samples were initially seen to have 'Burkholderia cepa$\mathrm{cia}^{\prime}$ growth and found that 8 of them were actually Herbaspirillum. The clonal relationship of the isolates was shown by PFGE (10). Spilker et al. also reported that 19 of the 28 patients with Herbaspirillum growth were originally identified as Burkholderia cepacian (6). In our cases, the isolates Herbaspirillum huttiens/ aquaticum, Burkholderia cepacia complex (BCC)/Cupriavidus pauculus and BCC were identified using Bruker MS, PhoenixTM and Vitek $2^{\circledR}$ Compact, respectively. Identification with MicroScan and VITEK MS was not possible; the isolates were identified as $99 \%$ Herbaspirillum huttiense by $16 \mathrm{~S}$ rDNA sequence analysis.

Because automated systems will provide identification for this organism (albeit an incorrect one), it is possible that an opportunistic infection may result from its underrecognition. Our outbreak demonstrates the utility of sequence-based identification of organisms, especially those that are not in the databases of commercial identification systems or are not readily identifiable using the conventional phenotypic methodology. The increased use and availability of relatively new molecular methods (e.g., MADI-TOF MS) should allow laboratories to correctly identify these organisms, considering the known issue of misidentification by established microbial identification systems (e.g., Vitek) (3).

In conclusion; Increasing the diagnostic power of clinical microbiology laboratories will help discover rare bacteria that may be pathogenic to prevent possible outbreaks.

Ethics Committe Approval: The study was approved by the Sisli Hamidiye Etfal Training and Research Hospital Ethics Committee $(\neq 825 / 17)$

Informed Consent: Patient consent was obtained.

Peer-review: Externally peer-reviewed.

Author Contributions: Concept - ND, BB, AO, AS, DE, LT, E.Aktas Design - ND, BB, AO, AS, LT; Supervision - ND; Resource - ND; Data Collection and/or Processing - All of authors; Analysis and/or Interpretation - ND, BB, AO, AS, DE, LT, BO; Literature Search - ND; Writing - ND; Critical Review - All of authors.

Conflict of Interest: All authors declare that they have no conflicts of interest or funding to disclose.

Financial Disclosure: The authors declared that this study has received no financial support.

\section{References}

1. Allegranzi B, Nejad SB, Combescure C, Graafmans W, Attar H, Donaldson $L$, et al. Burden of endemic health-care-associated infection in developing countries: systematic review and meta-analysis. The Lancet 2011;377(9761):228-41. [CrossRef]

2. Ziga ED, Druley T, Burnham C-AD. Herbaspirillum species bacteremia in a pediatric oncology patient. J Clin Microbiol 2010;48(11):4320-1. [CrossRef]

3. Regunath H, Kimball J, Smith LP, Salzer W. Severe community-acquired pneumonia with bacteremia caused by Herbaspirillum aquaticum or Herbaspirillum huttiense in an immune-competent adult. J Clin Microbiol 2015;53(9):3086-8. [CrossRef]

4. Suwantarat N, La'Tonzia LA, Romagnoli M, Carroll KC. Fatal case of Herbaspirillum seropedicae bacteremia secondary to pneumonia in an end-stage renal disease patient with multiple myeloma. Diagn Microbiol Infect Dis 2015;82(4):331-3. [CrossRef]

5. Baldani J, Pot B, Kirchhof G, Falsen E, Baldani V, Olivares F, et al. Emended description of Herbaspirillum; inccusion of [Pseudomonas] rubrisubalbicans, a mild plant pathogen, as Herbaspirillum rubrisubalbicans comb. Nov.; and classification of a Group of Clinical Isolates (EF Group 1) as Herbaspirillum species 3. Int J Syst Evol Microbiol 1996;46(3):802-10. [CrossRef]

6. Spilker T, Uluer AZ, Marty FM, Yeh WW, Levison JH, Vandamme P, et al. Recovery of Herbaspirillum species from persons with cystic fibrosis. J Clin Microbiol 2008;46(8):2774-7. [CrossRef]

7. Chen J, Su Z, Liu Y, Sandoghchian S, Zheng D, Wang S, et al. Herbaspirillum species: a potential pathogenic bacteria isolated from acute lymphoblastic leukemia patient. Curr Microbiol 2011;62(1):331-3. [CrossRef]

8. Tan MJ, Oehler RL. Lower extremity cellulitis and bacteremia with Herbaspirillum seropedicae associated with aquatic exposure in a patient with cirrhosis. Infect Dis Clin Pract 2005;13(5):277-9. [CrossRef]

9. da Silva RM, Caugant DA, Eribe ER, Aas JA, Lingaas PS, Geiran O, et al. Bacterial diversity in aortic aneurysms determined by 165 ribosomal RNA gene analysis. J Vasc Surg 2006;44(5):1055-60. [CrossRef]

10. Chemaly RF, Dantes $R$, Shah DP, Shah PK, Pascoe N, Ariza-Heredia E, et al. Cluster and sporadic cases of Herbaspirillum species infections in patients with cancer. Clin Infect Dis 2014;60(1):48-54. [CrossRef]

11. Wayne P. Clinical and laboratory standards institute. Performance standards for antimicrobial susceptibility testing. 2011. [CrossRef]

12. Durmaz R, Otlu B, Koksal F, Hosoglu S, Ozturk R, Ersoy Y, et al. The optimization of a rapid pulsed-field gel electrophoresis protocol for the typing of Acinetobacter baumannii, Escherichia coli and Klebsiella spp. Jpn J Infect Dis 2009;62(5):372-7. [CrossRef]

13. Kutty PK, Moody B, Gullion JS, Zervos M, Ajluni M, Washburn R, et al. Multistate outbreak of Burkholderia cenocepacia colonization and infection associated with the use of intrinsically contaminated alcohol-free mouthwash. Chest 2007;132(6):1825-31. [CrossRef]

14. Schreckenberger $P$, Daneshvar $M$, Weyant $R$, Hollis D. Acinetobacter, Achromobacter, Chryseobacterium, Moraxella, and Other Nonfermentative Gram-Negative Rods."Murray PR, Baron EJ, Pfaller MA, Landry $M L$, Jorgensen JH (eds). Manuel of Clinical Microbiology 9. baskı" kitabında s. 770-802. ASM Press, Washington; 2007. [CrossRef]

15. Winn WC. Koneman's color atlas and textbook of diagnostic microbiology: Lippincott williams \& wilkins; 2006. [CrossRef]

16. Marques AC, Paludo KS, Dallagassa CB, Surek M, Pedrosa FO, Souza EM, et al. Biochemical characteristics, adhesion, and cytotoxicity of environmental and clinical isolates of Herbaspirillum spp. J Clin Microbiol 2015;53(1):302-8. [CrossRef]

17. Ishii S, Yamamoto M, Kikuchi M, Oshima K, Hattori M, Otsuka S, et al. Microbial populations responsive to denitrification-inducing conditions in rice paddy soil, as revealed by comparative 16S rRNA gene analysis. Appl Environ Microbiol 2009;75(22):7070-8. [CrossRef] 